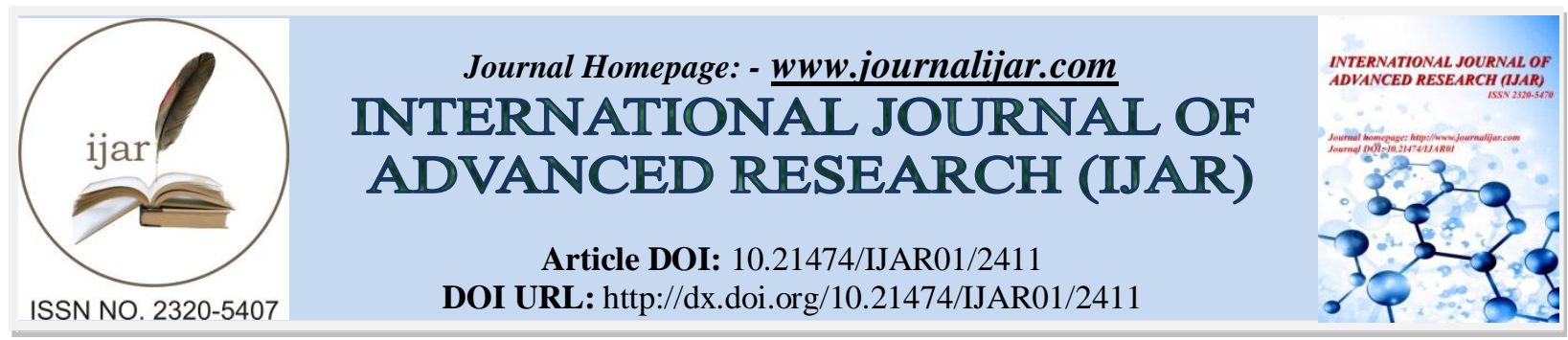

RESEARCH ARTICLE

\title{
A STUDY TO ASSESS THE KNOWLEDGE ON ILL EFFECTS OF JUNK FOODS AMONG I YEAR B.Sc., NURSING STUDENTS OF VINAYAKA MISSION'S COLLEGE OF NURSING, KARAIKAL.
}

Dr. K. Kamala, M.Sc.,(N)Ph.D.,

Principal, Vinayaka Mission's College Of Nursing, Karaikal.

\section{Manuscript Info}

Manuscript History

Received: 20 October 2016

Final Accepted: 22 November 2016

Published: December 2016

\section{Abstract}

A descriptive study was conducted to assess the knowledge on ill effects of Junk food among first year B.Sc Nursing students of Vinayaka Mission's College of Nursing, Karaikal. For this study 60 samples were selected by using Non probability convenient sampling technique. The data was collected through semi structured questionnaire. The results shows that out of 60 samples $58.34 \%$ were 18 years old, $75 \%$ were female, the maximum $80 \%$ students were Hindus, $83.3 \%$ students were belongs to nuclear family, $33.3 \%$ of parents were coolie, $31.7 \%$ students family monthly income was between Rs.3001- Rs.6000, 53.3\% were from urban area, 94\% were dayschlors, $80 \%$ were non-vegetarian and $60 \%$ of subjects were got information on junk foods from their parents. The study shows that the maximum 55\% students were having moderate level of knoweledge on ill effects of junk foods, $40 \%$ were having inadequate knowledge and $5 \%$ were having adequate knowledge .The present study reveals that there was no significant relationship between the students knowledge level on ill effects of junk foods with demographic variables.

\section{Introduction:-}

Food is one of the most important factor for better health. Our health depends on what we eat daily. The right selection and preference of food makes the person perfect in all their spheres. Now a days most of the people like Junk food and it is very popular among adult as well as in children. India's fast food industry is growing by $40 \%$ a year. India is in $10^{\text {th }}$ place in fast food per capita spending figures with $2.1 \%$ of expenditure of annual total spending. The preventable diseases caused mainly due to poor diet as Junk food consumption and lack of exercise could kill millions of people. The effects of Junk food include nutritional deficiency, obesity, increased cholesterol level, cardiac problems and many other threatening health hazards. A key role of nurses is to educate the people on various aspects about ill effects of Junk foods in a variety of settings such as schools, colleges, community organization, health fairs and child care centres.

\section{Need for the study:-}

Fast food affinity is equated with bad eating habits.. Most of these quick and convenient meals contain high amount of sodium, which increases and aggravates the risks of high blood pressure. In assessing the preventable causes of death, poor diet and physical activities accounts about 3,00,000 deaths per year globally. In 1953, fast food accounted for $4 \%$ of total sales of food outside the home, by 1997, it accounted for $34 \%$. As discretionary food 
expenditure, fast food doubled from $20 \%$ in the 1970 s to $40 \%$ by 1995 . It has been proved that majority of the adolescents had poor knowledge on health hazards of junk foods. This is mainly due to lack of education about dietary requirements. As an educator and health promoter, nurses have the responsibility to educate adolescents about health hazards of Junk food consumption. As a part of the education process, nurses should also assist families in formulating a plan to combat ill effects of junk foods.

\section{Statement of the problem:-}

A study to assess the knowledge on ill effects of junk foods among First year B.Sc., Nursing students of Vinayaka Mission's College of Nursing, Karaikal.

\section{Objectives:-}

- To assess the knowledge on ill effects of Junk foods among the students

- To find the association between the knowledge score with selected socio demographic variables.

\section{Methodology:-}

Quantitative research approach was adopted for this study. The research design chosen for the study was descriptive research design. Population of the study comprised of the students studying at Vinayaka Mission's College of Nursing, Karaikal. The study was conducted at First Year B.Sc., Nursing class room. Semi structured questionnaire was used to collect the data. Sample size of the study was 60 students. Non probability convenient sampling technique was adopted for selecting the samples.

\section{Data Analysis:-}

The data collected from subjects were grouped and analyzed using appropriate descriptive and inferential statistical tests.

Fig : Percentage distribution of students based on their level of knowledge on ill effects of junk foods

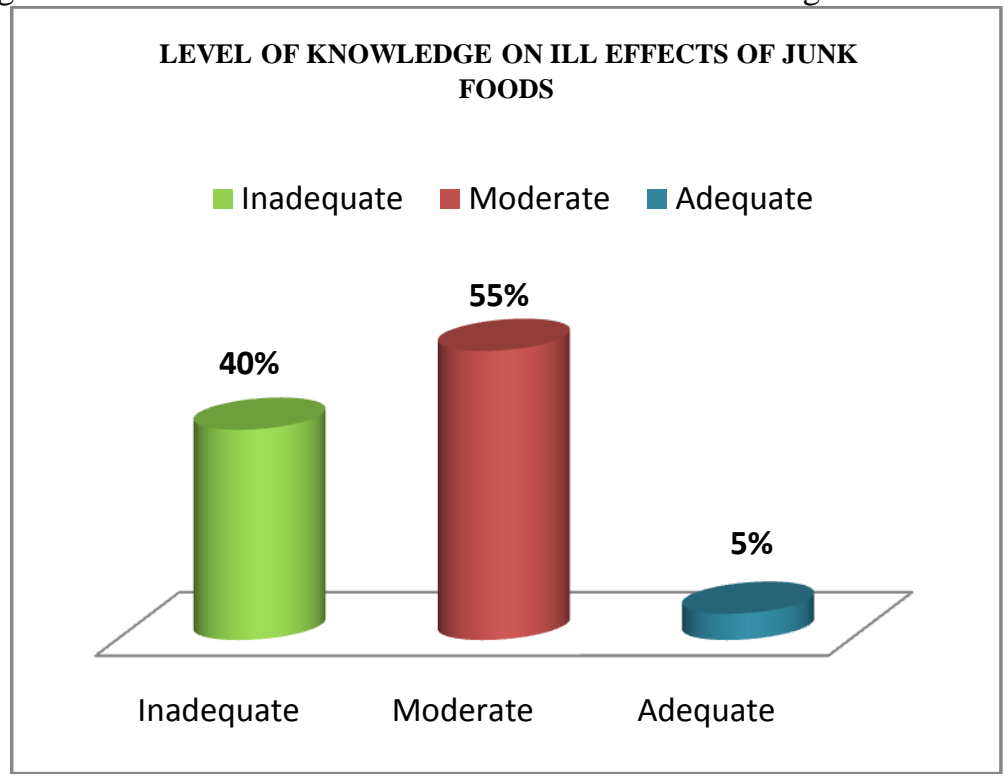

\section{Major Findings:-}

The results shows that out of 60 samples 35(58.34\%) were 18 years old, $45(75 \%)$ were female, 15 ( $20 \%$ ) were male, the maximum $48(80 \%)$ students were Hindus, 50(83.3\%) students were belongs to nuclear family, 20(33.3\%) of parents were coolie, 19(31.7\%) students family monthly income was between Rs.3001- Rs.6000 and 18 ( $30 \%$ ) students family income was more than Rs: 9001/-, 32(53.3\%) were from urban area, 28 ( $46.7 \%$ ) students were from rural, 54(94\%) were dayschlors, $48(80 \%)$ were non-vegetarian and 36(60\%) of subjects were got information on junk foods from their parents. 
The study shows that the maximum 55\% students were having moderate level of knoweledge on ill effects of junk foods, $40 \%$ were having inadequate knowledge and $5 \%$ were having adequate knowledge .

The present study reveals that there was no significant relationship between the students knowledge level on ill effects of junk foods with demographic variables.

\section{Conclusion:-}

The I year B.Sc., Nursing students knowledge regarding ill effects of Junk foods was assessed by using convenient sampling technique. In this study 33(40\%) were having inadequate (less than 50\%) knowledge. It shows that there is a need of improvement in awareness on ill effects of Junk foods.

\section{Recommendations:-}

On the basis of present study, following recommendations can be made

1. The study can be replicate by using a large sample there by findings can be generalized.

2. Various demographic details can be taken in various settings.

3. A comparative study can be conducted between adolescents and adults.

\section{References:-}

1. Basavanthappa.B.T.(2007), NURSING THEORIES, First edition, Jaypee brothers medical publishers(p)Ltd, New Delhi, page .no 665-669.

2. Darshan Sohi(2009), Text book of nutrition, $2^{\text {nd }}$ edition, P.K.Jain publishers, Jalandar, page no:87-90.

3. Desai,A.B.(2006), TEXT BOOK OF PAEDIATRICS, $3^{\mathrm{RD}}$ EDITION,Orient Longman publishers, Madras, page no:334-338

4. Dorothy and Marlow,(1996), TEXT BOOK OF PAEDIATRICS, $6^{\text {th }}$ edition, W.B. Saunders company Publishers, page .no:253-259.

5. Ghai O.P.(2007),ESSENTIAL PAEDIATRICS, $6^{\text {th }}$ edition, new CBS Publishers and distributors,New Delhi, page.no:574-577.

6. Indrani.T.K(2008). NURSING MANUAL OF NUTRITION AND THERAPEUTIC DIET, page no:103-105.

7. Joyce.M.Black (2001), MEDICAL SURGICAL NURSING, $6^{\mathrm{TH}}$ edition , C.V Mosby publications,London,pageno-548-552

8. Park.K (2007),TEXT BOOK OF PREVENTIVE AND SOCIAL MEDICINE, $9^{\text {th }}$ edeition,banarsidas Bhanot Publishers,Japalpur,page no:653-660

9. Paul.Insel(2008),THE TEXT BOOK OF ESENTIAL OF FOOD AND NUTRITION,Lotus publishers,page no: $87-90$

10. Shabnam Mash(2008), ESENTIAL OF FOOD AND NUTRITION,Lotus publishers,page no:105-108

11. Swaminathan.M(2010), THE TEXT BOOK OF FOOD AND NUTRITION, $5^{\mathrm{TH}}$ edition,page no:79-83

12. Swaminathan.M(2010),HAND BOOK OF FOOD AND NUTRITION,5 th edition,page no:65-67

13. Burtiiw.etal,(2006), World healthn forum,journal of clinical nutrition,page no:404-406

14. Siege-Riz.A.M,(2005),Adolescent health,Page no:29-36

15. http://news.bbc.co.uk/2/hi/

16. http://snackentertainment.com 